\title{
Structure of Fejes Tóth cells in natural honey bee combs
}

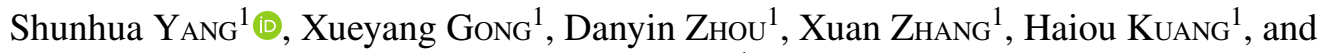 \\ Kun Dong ${ }^{1}$ \\ ${ }^{1}$ Yunnan Provincial Engineering and Research Center for Sustainable Utilization of Honeybee Resources, Eastern Bee \\ Research Institute, College of Animal Science and Technology, Yunnan Agricultural University, Kunming 650201, \\ China
}

Received 30 September 2021 - Revised 10 December 2021 - Accepted 30 December 2021

\begin{abstract}
We present an analysis of the structure of Fejes Tóth cells in the natural combs of the Chinese bee, Apis cerana cerana (Hymenoptera: Apidae), and the Italian bee, Apis mellifera ligustica (Hymenoptera: Apidae). The proportion of Fejes Tóth cells in the natural combs built by bee colonies was determined. Molds of Fejes Tóth cells and three-rhombus cells were used to measure various structural parameters, such as the diameter and depth of Fejes Tóth cells and three-rhombus cells. Both Chinese bees and Italian bees built an average of no more than $18 \%$ Fejes Tóth cells on natural combs. The dihedral angle of the two hexagonal planes at the bottom of the Fejes Tóth cells was significantly less than $120^{\circ}$. No significant differences in the diameter and depth of Fejes Tóth cells and three-rhombus cells were observed. The results of this study clarified the structural characteristics of Fejes Tóth cells in natural combs. These data will aid the manufacture of Fejes Tóth wax comb foundations specifically and the growth of the beekeeping industry more generally.
\end{abstract}

\section{Honey bee / Comb / Fejes Tóth cell / Three-rhombus cell / Comb foundation}

\section{INTRODUCTION}

Honey bees are some of nature's best architects for their ability to build large nests with small amounts of building materials, and their combs are some of the most spectacular structures found in nature. The hexagonal prism comb cells that they build (without the aid of measuring tools) are composed of three congruent rhombuses at the bottom (Kepler 1619) with the following angular features: obtuse angle of the rhombus at the bottom of the cell, $109^{\circ} 28^{\prime}$; acute angle of the rhombus at the bottom of the cell, $70^{\circ} 32^{\prime}$; dihedral angle formed by each rhombus face and the cell wall, $120^{\circ}$; and dihedral angle

Corresponding author: K. Dong,

dongkun19722004@aliyun.com

Manuscript editor: Klaus Hartfelder formed between the rhombus faces, $120^{\circ}$. Hexagonal comb cells with these features are thought to have the smallest possible surface area, largest volume, and thus highest storage capacity compared with alternative cell structures (MacLaurin 1743; Sharpe 1828; Glaisher 1873; Hennessy 1885; Everett 1903; Graesser 1946) (Figure 1a).

Combs are composed of thousands of hexagonal cells. Adjacent hexagonal cells on the same comb surface share a cell wall, and hexagonal cells on different comb surfaces share a cell bottom. The cell walls and bottoms are relatively thin. The thickness of the cell wall is $0.073 \mathrm{~mm} \pm 0.002 \mathrm{~mm}$ (Frisch and Frisch 1974; Tautz 2008), and the thickness of the cell bottom is $0.176 \mathrm{~mm} \pm 0.028 \mathrm{~mm}$ (Seeley 1985). These features greatly reduce the costs of cell construction for honey bees. However, Tóth (1964) showed that there exists a more economical cell 
S. Yang et al.

(a)
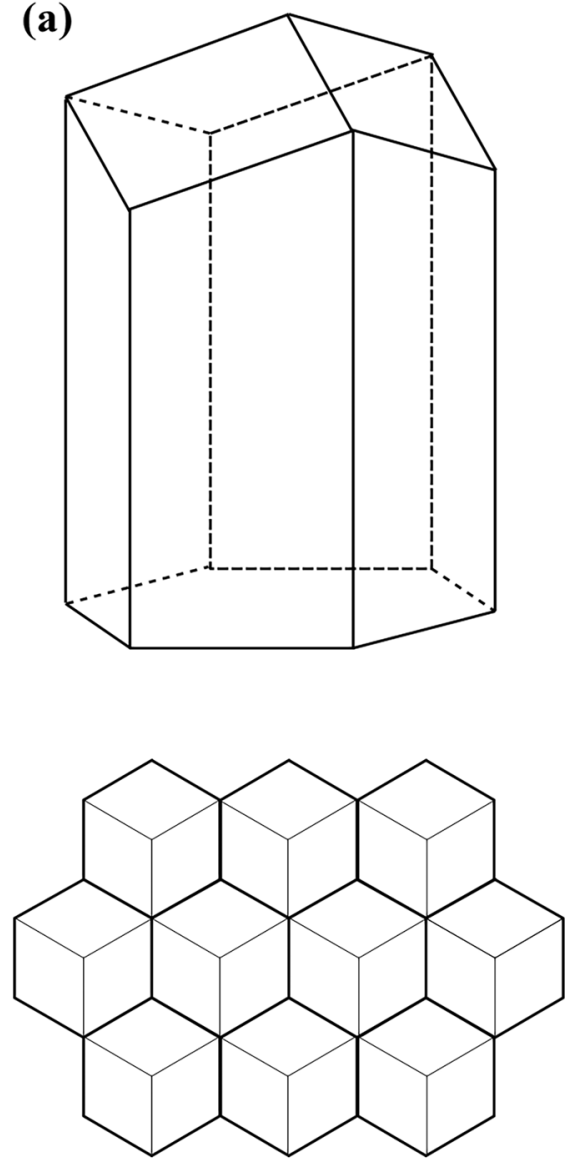

(b)
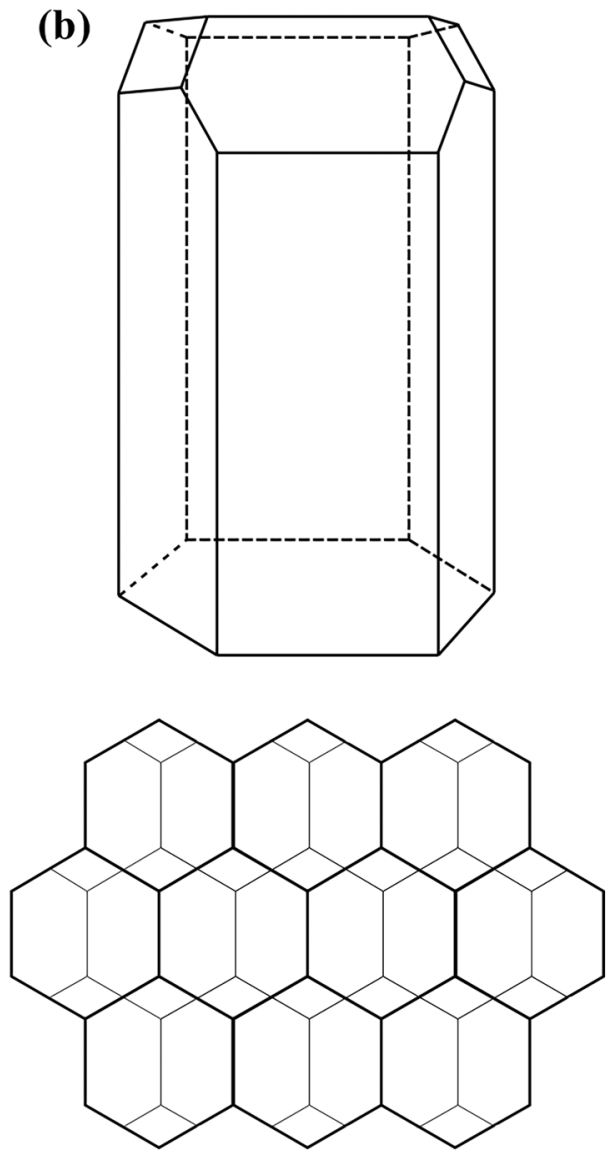

Figure 1. Schematic diagrams of honey bee comb cells. a Three-rhombus cell; b Fejes Tóth structure. Based on Tóth (1964)

structure in theory (Figure 1b), which made some question whether honey bees were the talented architects that they were originally assumed to be. However, the Irish physicists Weaire and Phelan (1994) later argued using an analogy of soap bubbles that the Fejes Tóth structure is only closer to the theoretical optimum in the absence of beeswax on the surface of the Fejes Tóth cells; thus, the three-rhombus structure of honey bee comb cells is closer to the theoretical optimum in biological contexts.

Although the results of Tóth (1964) and Weaire and Phelan (1994) are discussed in subsequent studies (Mackenzie 1999; Peterson 1999), little headway was made in this area until Vallo et al. (2014) used interactive geometry software to show that the structure proposed by Fejes Tóth is theoretically possible and requires fewer construction materials than the three-rhombus cell structure, and this finding has renewed interest in the Fejes Tóth structure (Räz 2017; Svečnjak et al. 2019). Räz (2017) described two types of honey bee comb cell structures: the three-rhombus structure (i.e., the three-rhombus cell, as the cell base of the three-rhombus cell is composed of three rhombus structures) and the Fejes Tóth structure (i.e., Fejes Tóth cell). Early studies of honey bee comb cell construction in the nineteenth century identified the presence of four planes at the bottom of the cell (Huber 1814; Wyman 1866): two symmetrical rhombuses and two symmetrical hexagons. Oelsen and Rademacher (1979) also reported a 
novel "rosette" cell structure. We speculate that the comb cells discovered by Huber (1814) and Wyman (1866) and Oelsen and Rademacher (1979) may be the Fejes Tóth cells reported by Fejes Tóth (1964) and Vallo et al. (2014). Our preliminary observations suggest that three-rhombus cells and Fejes Tóth cells are present in the natural combs of the Chinese bee, Apis cerana cerana (Hymenoptera: Apidae), and the Italian bee, Apis mellifera ligustica (Hymenoptera: Apidae). Much research has examined the structure and dimensions of honey bee comb cells (Hepburn et al. 2014; Saucy 2014; Nazzi 2016; Svečnjak et al. 2019) as well as their formation mechanism; this work has provided important insights into how honey bees build combs (Pirk et al. 2004; Bauer and Bienefeld 2013; Karihaloo et al. 2013; Hepburn et al. 2014; Oldroyd and Pratt 2015; Nazzi 2016; Oeder and Schwabe 2017; Jeong et al. 2018, 2019; Narumi et al. 2018; Talukdar and Dutta 2019). However, the structure and size of Fejes Tóth cells have not yet been characterized.

In 1857, Johannes Mehring produced the first wax comb foundation, which has since been widely used in beekeeping (Manby 1932). Beeswax is the main material used for the wax comb foundation, and wax comb foundation machines can be used to roll beeswax sheets with standard honey bee comb cell bases (Johansson and Johansson 1969; Pellett 2010; Khamdaeng et al. 2016). Wax comb foundations can be placed into movable-frame Langstroth hives. The worker bees secrete beeswax and use it in addition to the wax comb foundation to form a complete wax comb. Wax comb foundations allow bees to quickly construct a flat and uniform comb with less honey, which facilitates the breeding and management of bee colonies (Smith 1960) and makes modern commercial beekeeping possible. The wax comb foundation is thus indispensable for modern scientific beekeeping. The cell base structure of the wax comb foundation used in beekeeping is based on the structure of a standard natural honey bee comb cell base, and the wax comb built by bee colonies using the current comb foundation has the structure of standard comb cells. However, a single Fejes Tóth cell saves $0.35 \%$ more beeswax than a three-rhombus cell (Tóth 1964). Given that the comb of a Langstroth standard movable frame has approximately 6000 cells, the amount of beeswax saved by a comb with all Fejes Tóth cells is potentially considerable compared with a comb composed of three-rhombus cells. Seeley (1985) estimated that the construction of a nest with 100,000 three-rhombus cells would require over $1200 \mathrm{~g}$ of beeswax, which (in a typical nest) is energetically equivalent to approximately $7.5 \mathrm{~kg}$ of honey. The construction of a single Fejes Tóth cell requires $0.042 \mathrm{mg}$ of beeswax less than the construction of a three-rhombus cell. Given that bees secrete $0.042 \mathrm{mg}$ of beeswax to consume at least $0.2625 \mathrm{mg}$ of honey, the water content of nectar is approximately four times that of honey, and the honey stomach capacity of a bee is $60 \mu \mathrm{l}$ (Oeder and Schwabe 2021); brewing $0.2625 \mathrm{mg}$ of honey would require at least 20 nectar-collecting trips. The properties of Fejes Tóth comb foundation and the structural parameters of Fejes Tóth cells thus require investigation.

Here, we used natural honey bee combs to determine the proportion of Fejes Tóth cells in combs and measure structural parameters of Fejes Tóth cells to provide data that could be used to support the manufacture of a Fejes Tóth wax comb foundation machine. First, the number and percentage of Fejes Tóth cells and the total number of cells on each natural comb were determined. Molds of Fejes Tóth cells and three-rhombus cells were made, and these molds were then used to measure the size of the dihedral angle of the two hexagonal planes and the length of each side of the polygon at the bottom of Fejes Tóth cells. The diameter and depth of Fejes Tóth cells and threerhombus cells were also measured and compared. The results of this research will aid the development of Fejes Tóth comb foundations and have important implications for modern beekeeping.

\section{MATERIALS AND METHODS}

\subsection{Natural comb construction}

This research was conducted in the apiary of Yunnan Agricultural University, which is located in Kunming, Yunnan Province. Colonies of 
Chinese bees (A. c. cerana) and Italian bees ( $A$. $m$. ligustica) were set up in standard movableframe Langstroth hives. There were 37 colonies of Chinese bees, and four frames were fully covered by adult bees. There were 53 colonies of Italian bees, and seven frames were fully covered by adult bees. In both sets of colonies, queens were of the same age, and colonies were of similar strength.

The hives of each colony were divided into two areas by a vertical queen excluder. Each area in the Chinese beehive had two wax combs. The Chinese bee queen laid eggs in one of two areas, and an empty movable frame was added into the other area to build natural comb. There were three combs in one area of the Italian beehive to rear broods, and there were four combs in another area where an empty frame was added to build natural comb.

Each colony was fed sugar syrup every evening during comb-building until the inner area of the empty frame was completely occupied by the wax comb. The new natural comb was transferred to the outside of the following board in the same hive to facilitate the ability of bees to clean food stored in the comb. After the comb was cleaned, it was taken out of the hive and sent to the laboratory to make comb cell molds.

\subsection{Numbers and percentages of Fejes Tóth cells in natural combs}

A standard empty movable frame was modified into a measuring tool with square grids, and the number of cells was measured through the grids. The number of cells in each grid and the number of cells with different structures were then counted. A strong cold light source was used to facilitate the identification of Fejes Tóth cells and three-rhombus cells. The total number of cells (C) in each newly built natural comb was counted. If the natural comb had both worker and drone cells, then the total number of worker cells (WC), the total number of drone cells (DC), the number of worker Fejes Tóth cells (WTCs), and the number of drone Fejes Tóth cells (DTC) were determined. If the comb had only one type of cell (worker cells or drone cells), the number of Fejes Tóth cells (WTC or DTC) was calculated. The percentages were calculated using the following formulas: $\mathbf{w}_{\mathbf{1}}=\mathrm{WC} / \mathrm{C} \times 100 \%$, $\mathbf{w}_{\mathbf{2}}=\mathrm{DC} / \mathrm{C} \times 100 \%, \quad \mathbf{w}_{\mathbf{3}}=\mathrm{WTC} / \mathrm{C} \times 100 \%$, $\mathbf{w}_{\mathbf{4}}=\mathrm{DTC} / \mathrm{C} \times 100 \%, \mathbf{w}_{\mathbf{5}}=\mathrm{WTC} / \mathrm{WC} \times 100 \%$, and $\mathbf{w}_{\mathbf{6}}=\mathrm{DTC} / \mathrm{DC} \times 100 \%$.

\subsection{Preparation of cell molds}

On both sides of each comb, ten WTCs were randomly selected and used to make WTC molds. At least three Fejes Tóth cells were randomly selected and used as experimental samples in each cluster of Fejes Tóth cells in each natural comb until a total of ten Fejes Tóth cells were selected in each cluster of Fejes Tóth cells. Ten DTCs were randomly selected and used as samples to make DTC molds. In addition, ten actual comb worker cells were randomly selected and used as samples to make worker cell molds, and ten actual comb drone cells were used as samples to make drone cell molds.

After the frame with newly built comb was oriented horizontally, the crystal glue solution was prepared using epoxy resin and its curing agent (volume ratio $1: 1$ ); it was then drawn into a disposable syringe and injected into the previously selected cells. A sufficient amount of crystal glue solution was injected so that it remained flush with the cell mouth. After $12 \mathrm{~h}$ at room temperature, the crystal glue solution in the comb cell solidified, forming a fixed shape and hardened cell mold. During the crystal glue curing process, heat was not emitted, the shape of the comb cells did not change, and the volume of the cell mold did not shrink or expand. Thus, the structure and size of the comb cell molds and the comb cells were the same. The comb was soaked in $90{ }^{\circ} \mathrm{C}$ water, and the beeswax absorbed melted. The molds were automatically separated from each other, and the beeswax on the surface of the cell molds was melted to obtain clean cell molds. The hardness of the cell mold was greater than $80 \mathrm{HD}$, and it did not deform in $90^{\circ} \mathrm{C}$ water. Therefore, the structure and size of the cell mold reflected the actual structure and size of the honey bee comb cells. 


\subsection{Measurements of comb cell molds}

Cells with Fejes Tóth structure were denoted as FTC, and cells with three-rhombus structure were denoted as TRC (FTC stands for Fejes Tóth cells, and TRC stands for three-rhombus cells). $N_{\text {combs }}$ represents the number of combs, and $N_{\text {cell }}$ represents the total number of cells of $N_{\text {combs }}$. The dihedral angle of the two hexagonal planes at the bottom of Fejes Tóth cells was measured using an electronic protractor (accuracy $\pm 0.01^{\circ}$ ). Vernier calipers (accuracy $\pm 0.01 \mathrm{~mm}$ ) were used to measure the diameter and height (cell depth) of the cell molds; the diameters of each cell mold were measured three times, and the average value of the three diameters was calculated. Side lengths $\mathrm{AB}, \mathrm{BK}, \mathrm{KJ}$, and JA for quadrilateral ABKJ and side lengths EF, FG, GL, and EL for quadrilateral EFGL at the bottom of Fejes Tóth cells were measured; side lengths $\mathrm{BC}, \mathrm{CD}, \mathrm{DE}$, $\mathrm{EL}, \mathrm{KL}$, and BK for hexagon JKLGHI and side lengths GH, HI, IJ, KJ, KL, and GL for hexagon
BCDELK at the bottom of Fejes Tóth cells were measured (Figure 2).

\subsection{Statistical analysis}

The data were analyzed using SAS v8.0 software (SAS Institute Inc., North Carolina, USA). Differences in the dihedral angle and theoretical angle $\left(120^{\circ}\right)$ of the two hexagonal planes at the bottom of the Fejes Tóth cells were determined using a one-sample $t$-test. Differences in the diameter between the honey bee Fejes Tóth cell molds and the three-rhombus cell molds were assessed by an independent sample $t$-test. Differences in the height between honey bee Fejes Tóth cell molds and the three-rhombus cell molds were assessed by an independent sample $t$-test. The average side lengths of the two quadrilaterals and two hexagons at the bottom of the Fejes Tóth cell molds were calculated. Data were presented as mean \pm standard error.

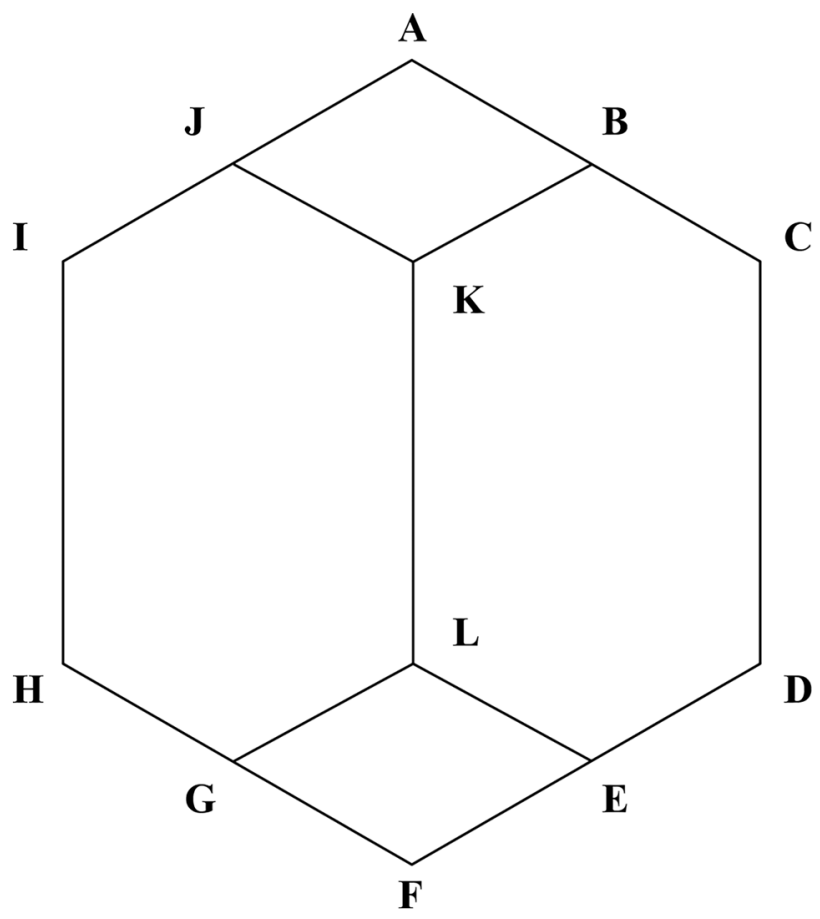

Figure 2. Front projection of the base of a Fejes Tóth cell 


\section{RESULTS}

\subsection{Fejes Tóth cells, three-rhombus cells, and their molds}

While managing the Chinese and Italian bee colonies, we found that the natural comb contains some cells with special structures. Four polygonal planes are located at the bottom of these cells (two hexagons and two quadrilaterals) and six cell walls, including four pentagonal planes and two rectangular planes. The two hexagonal planes have positional symmetry, and the dimensions appear to be the same; the two quadrilaterals have the same characteristics as mentioned above. Tóth (1964) indicated that the aforementioned cells are in fact Fejes Tóth cells. We took photos and made molds of the Fejes Tóth cells of natural Chinese bee combs (Figure 3 ). We also took photos and made molds of three-rhombus cells of natural Chinese bee combs (Figure 4). There were several clusters of Fejes Tóth cells on each natural comb, and clusters of Fejes Tóth cells were randomly distributed on both sides of the comb. The clusters of Fejes Tóth cells on one side of the comb corresponded to the clusters of Fejes Tóth cells on the other side of the comb; in other words, the distribution of Fejes Tóth cells on both sides of the comb was symmetrical. The WTC (a)
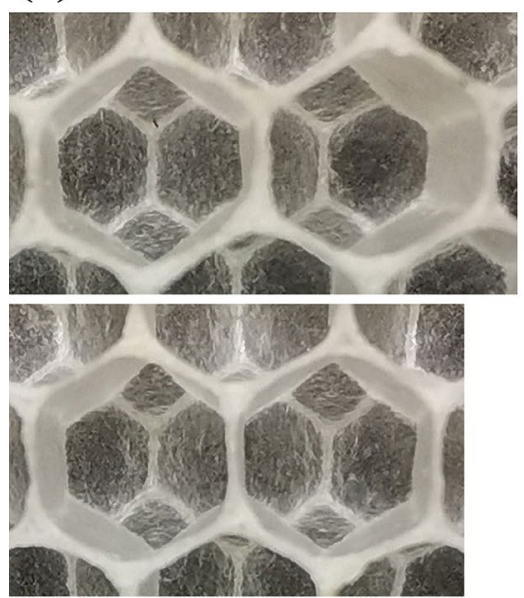

(b)
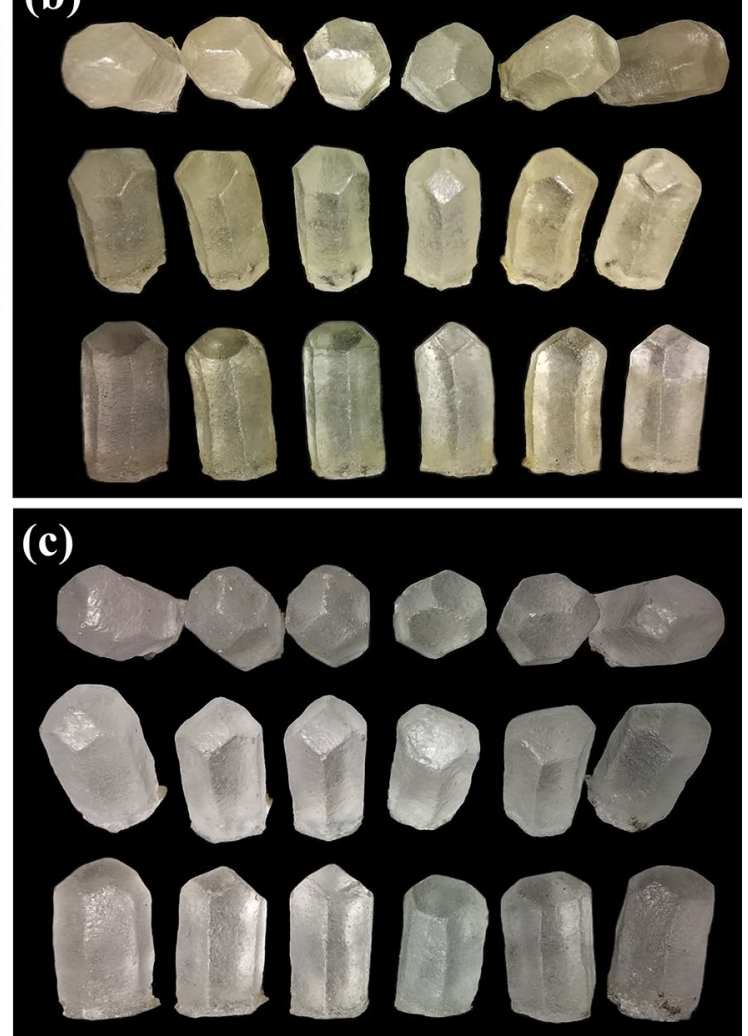

Figure 3. a Photos of Fejes Tóth cells of natural Chinese bee worker combs. b Molds of Fejes Tóth cells of natural Chinese bee worker combs. c Molds of Fejes Tóth cells of natural Chinese bee drone combs 
(a)

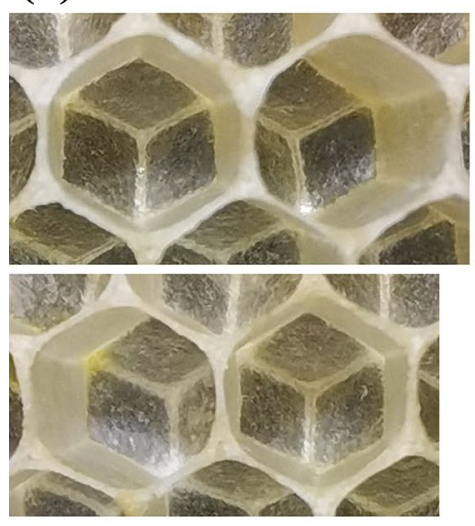

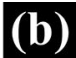
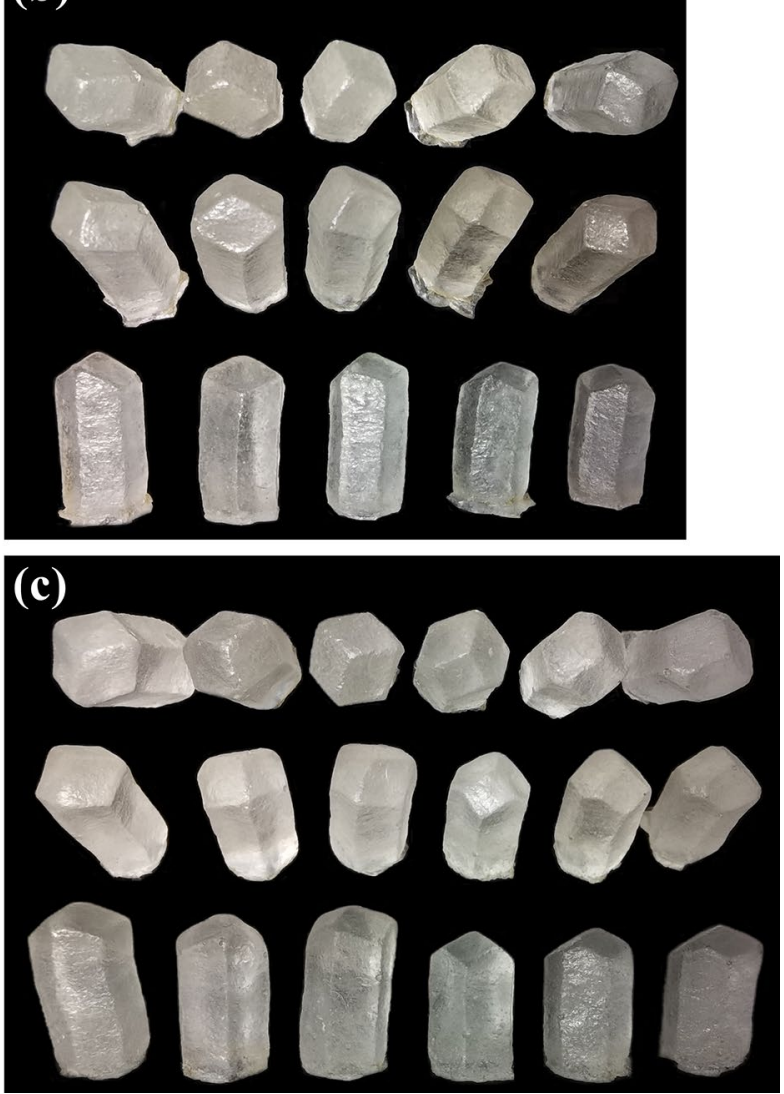

Figure 4. a Three-rhombus cells of natural Chinese bee worker combs. b Molds of three-rhombus cells of natural Chinese bee worker combs. $\mathbf{c}$ Molds of three-rhombus cells of natural Chinese bee drone combs

of natural combs of Chinese bees are shown in Figure 5a, and the cell walls of these cells are absent in Figure 5b. Irregular cells were present at the boundary between Fejes Tóth cells and three-rhombus cells; these cells were neither Fejes Tóth cells nor three-rhombus cells and are indicated by the red circles in Figure 5b. The Chinese worker bee cells of natural combs are shown in Figure $6 a$, and the cell walls of these cells are absent in Figure $6 b$.

\subsection{Percentage of Fejes Tóth cells in natural combs}

\subsubsection{Chinese bee combs}

Natural combs were constructed by each of 37 Chinese bee colonies, including 23 worker combs, six drone combs, and eight mixed combs (i.e., combs with both worker cells and drone cells). The average percentage of WTC 
(a)

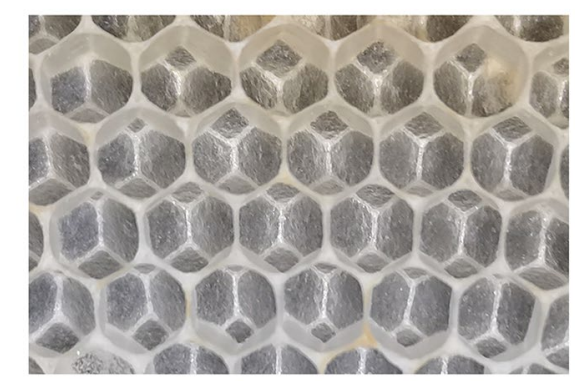

(b)

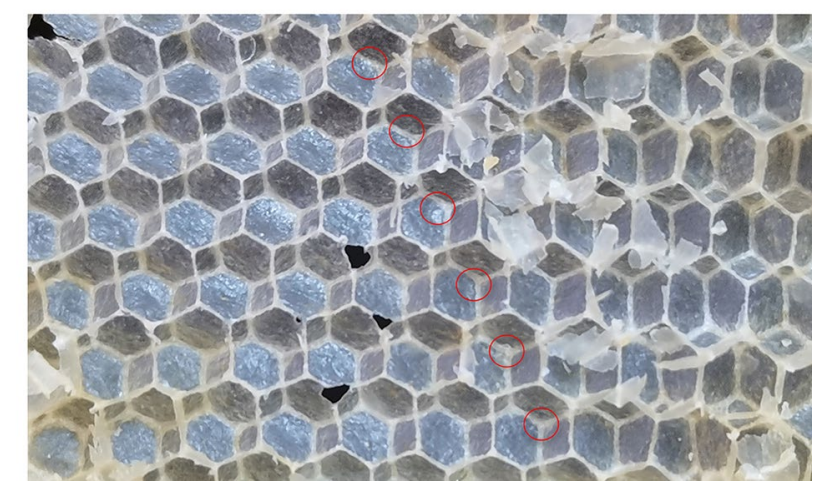

Figure 5. a Fejes Tóth cells of the natural combs of Chinese bees. Photograph of Chinese worker bee cells of natural combs a with and $\mathbf{b}$ without cell walls

to $\mathrm{C}\left(\mathbf{w}_{\mathbf{3}}\right)$ was $14.48 \% \pm 0.97 \%\left(N_{\text {comb }}=23\right.$, $\left.N_{\text {cell }}=144,175\right)$ (Figure 7a). The average percentage of DTC to C $\left(\mathbf{w}_{4}\right)$ was $4.89 \% \pm 1.26 \%$ $\left(N_{\text {comb }}=6, N_{\text {cell }}=16,016\right)$ (Figure 7a).

For mixed combs, the average percentage of WC to $\mathrm{C}\left(\mathbf{w}_{1}\right)$ was $86.16 \% \pm 1.74 \%\left(N_{\text {comb }}=8\right.$, $\left.N_{\text {cell }}=48,101\right)$, the average percentage of WTC to $\mathrm{C}\left(\mathbf{w}_{\mathbf{3}}\right)$ was $11.16 \% \pm 1.47 \%\left(N_{\text {comb }}=8\right.$, $\left.N_{\text {cell }}=48,101\right)$, and the average percentage of WTC to WC $\left(\mathbf{w}_{\mathbf{5}}\right)$ was $12.87 \% \pm 1.58 \%$ $\left(N_{\text {comb }}=8, N_{\text {cell }}=48,101\right)$ (Figure $\left.7 \mathrm{~b}\right)$. Furthermore, the average percentage of DC to $\mathrm{C}\left(\mathbf{w}_{\mathbf{2}}\right)$ was $13.84 \% \pm 1.74 \%\left(N_{\text {comb }}=8, N_{\text {cell }}=48,101\right)$, the average percentage of DTC to $\mathrm{C}\left(\mathbf{w}_{\mathbf{4}}\right)$ was $0.54 \% \pm 0.27 \%\left(N_{\text {comb }}=8, N_{\text {cell }}=48,101\right)$, and the average percentage of DTC to DC $\left(\mathbf{w}_{\mathbf{6}}\right)$ was $4.92 \% \pm 2.70 \%\left(N_{\text {comb }}=8, N_{\text {cell }}=48,101\right)$ (Figure 7b).

\subsubsection{Italian bee combs}

Natural combs were built by 53 Italian bee colonies, including 24 worker combs, four drone combs, and 25 mixed combs. For the worker bee combs, the average percentage of WTC to $\mathrm{C}\left(\mathbf{w}_{\mathbf{3}}\right)$ was $8.52 \% \pm 0.77 \%\left(N_{\text {comb }}=24, N_{\text {cell }}=133,279\right)$ (Figure 7c). For the drone combs, the average percentage of DTC to $\mathrm{C}\left(\mathbf{w}_{\mathbf{4}}\right)$ was $8.27 \% \pm 3.80 \%$ $\left(N_{\text {comb }}=4, N_{\text {cell }}=15,760\right)$ (Figure $\left.7 \mathrm{c}\right)$. 


\section{(a)}

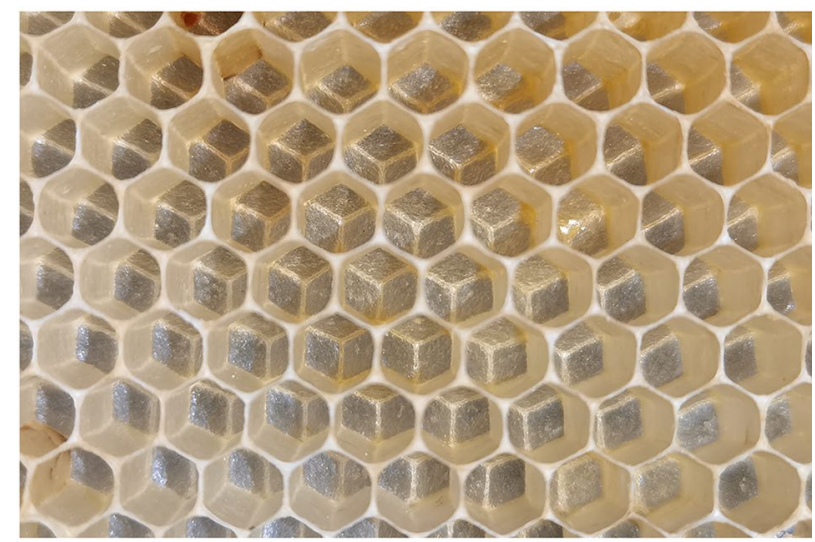

(b)

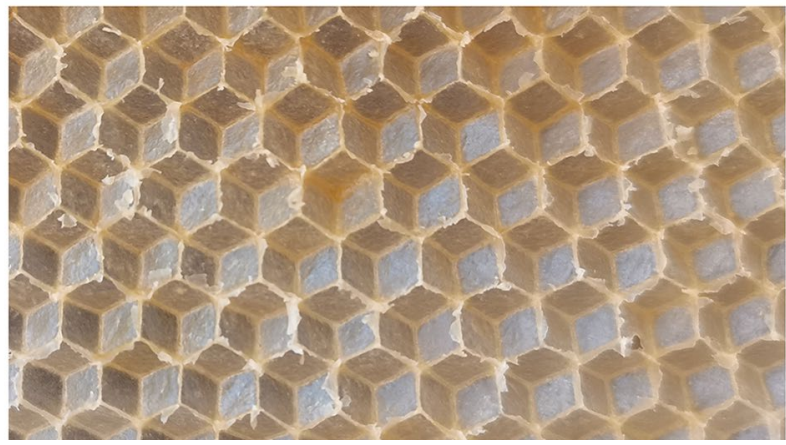

Figure 6. Three-rhombus cells of the natural combs of Chinese bee workers. Photograph of Chinese worker bee cells of natural combs $\mathbf{a}$ with and $\mathbf{b}$ without cell walls

For mixed combs, the average percentage of WC to $\mathrm{C}\left(\mathbf{w}_{1}\right)$ was $64.00 \% \pm 4.51 \%\left(N_{\text {comb }}=25\right.$, $\left.N_{\text {cell }}=118,519\right)$, the average percentage of WTC to $\mathrm{C}\left(\mathbf{w}_{3}\right)$ was $11.34 \% \pm 1.22 \%\left(N_{\text {comb }}=25\right.$, $\left.N_{\text {cell }}=118,519\right)$, and the average percentage of WTC to WC $\left(\mathbf{w}_{\mathbf{5}}\right)$ was $17.84 \% \pm 1.56 \%$ $\left(N_{\text {comb }}=25, N_{\text {cell }}=118,519\right)$ (Figure $\left.7 d\right)$. Furthermore, the average percentage of DC to $\mathrm{C}\left(\mathbf{w}_{\mathbf{2}}\right)$ was $36.00 \% \pm 4.51 \%\left(N_{\text {comb }}=25, N_{\text {cell }}=118,519\right)$, the average percentage of DTC to $\mathrm{C}\left(\mathbf{w}_{\mathbf{4}}\right)$ was $5.80 \% \pm 1.00 \%\left(N_{\text {comb }}=25, N_{\text {cell }}=118,519\right)$, and the average percentage of DTC to DC $\left(\mathbf{w}_{\mathbf{6}}\right)$ was $14.67 \% \pm 1.19 \%\left(N_{\text {comb }}=25, N_{\text {cell }}=118,519\right)$ (Figure 7d).

\subsection{Dihedral angles of the two hexagonal planes at the bottom of Fejes Tóth cells}

\subsubsection{Chinese bee combs}

The two hexagons at the bottom of the Fejes Tóth cells were denoted as JKLGHI and BCDELK, and their common side was KL (Figure 2). According to Tóth (1964), the theoretical dihedral angle of the two hexagonal planes (JKLGHI and BCDELK; Figure 2) of Fejes Tóth cells is $120^{\circ}$. The average dihedral angle between the hexagonal plane JKLGHI and the hexagonal 

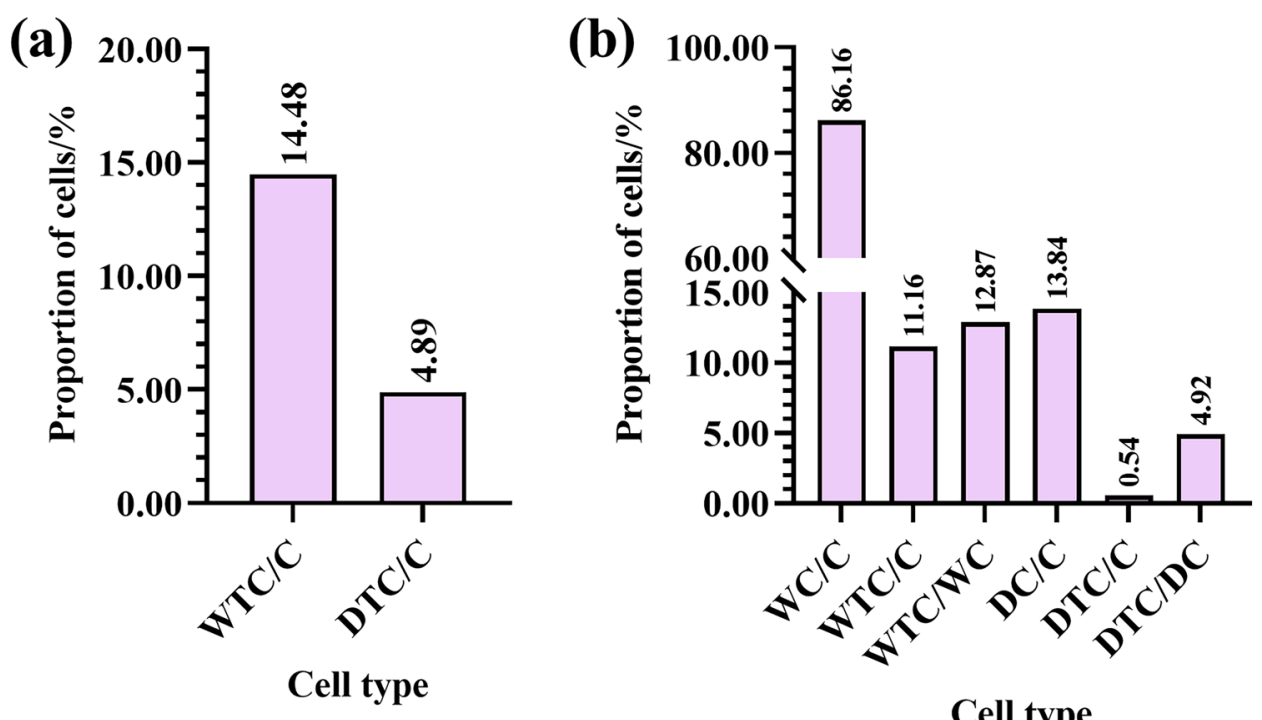

\section{Cell type}

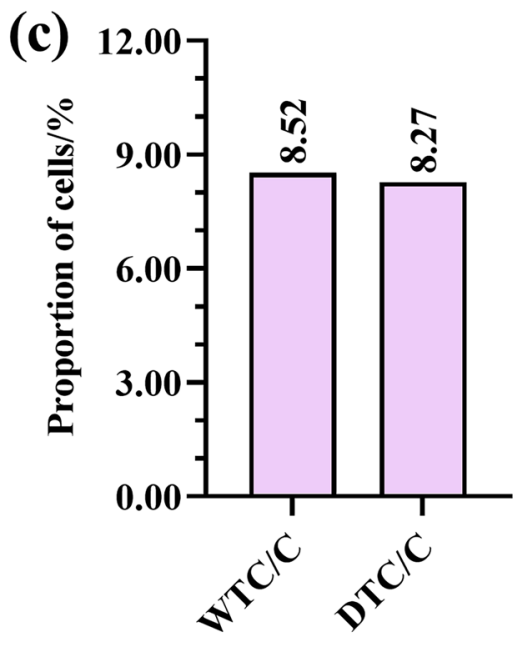

Cell type (d)

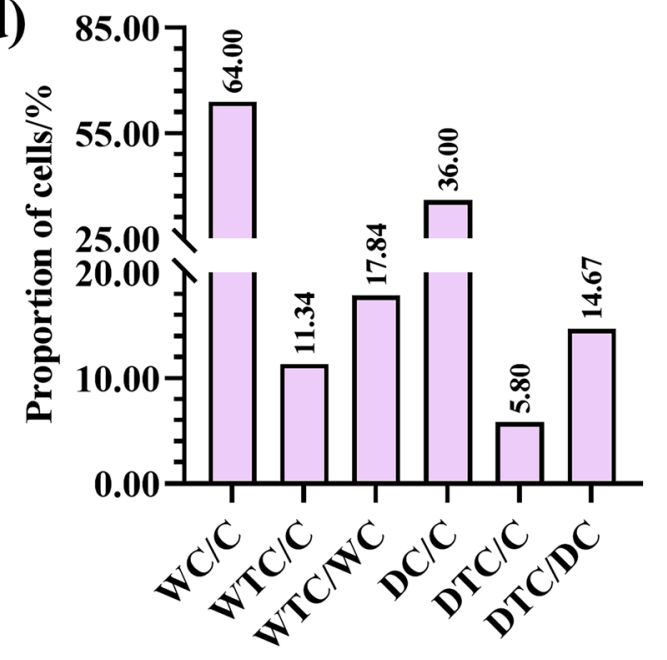

Cell type

Figure 7. Percentage of Fejes Tóth cells in Chinese bee (A. c. cerana) natural combs. a Percentage of worker Fejes Tóth cells (WTC) to total cells (C) of worker bee combs and percentage of drone Fejes Tóth cells (DTC) to C of drone bee combs. b Percentage of worker cells (WC) and drone cells (DC) to C, percentage of worker Fejes Tóth cells (WTC) and drone Fejes Tóth cells (DTC) to C, and percentage of WTC to WC and DTC to DC in mixed combs (i.e., combs with both worker and drone cells). Percentage of Fejes Tóth cells in Italian bee (A. m. ligustica) natural combs. $\mathbf{c}$ Percentage of WTC to C of worker bee combs and percentage of DTC to C of drone bee combs. d Percentage of WC and DC to C, percentage of WTC and DTC to C, and percentage of WTC to WC and DTC to DC in mixed combs. Note that $C$ was counted in each newly built natural comb. If the natural comb had both worker and drone cells, then WC, DC, WTCs, and DTC were determined. If the comb had only one type of cell (worker cells or drone cells), the corresponding number of Fejes Tóth cells (WTC or DTC) was calculated 
plane BCDELK at the bottom of the WTC was $108.70^{\circ} \pm 0.16^{\circ}\left(N_{\text {comb }}=23, N_{\text {cell }}=238\right)$, which is significantly lower than the theoretical value of $120^{\circ}(t=71.43, \mathrm{df}=237, P<0.0001)$. The average dihedral angle between the hexagonal plane JKLGHI and the hexagonal plane BCDELK at the bottom of the DTC was $109.60^{\circ} \pm 0.44^{\circ}$ $\left(N_{\text {comb }}=6, N_{\text {cell }}=68\right)$, which is significantly lower than the theoretical value of $120^{\circ}(t=23.34$, $\mathrm{df}=67, P<0.0001)$. The dihedral angle data are shown in Figure 8a.

\subsubsection{Italian bee combs}

The two hexagons at the bottom of the Fejes Tóth cells were denoted as JKLGHI and BCDELK, and their common side was

(a)

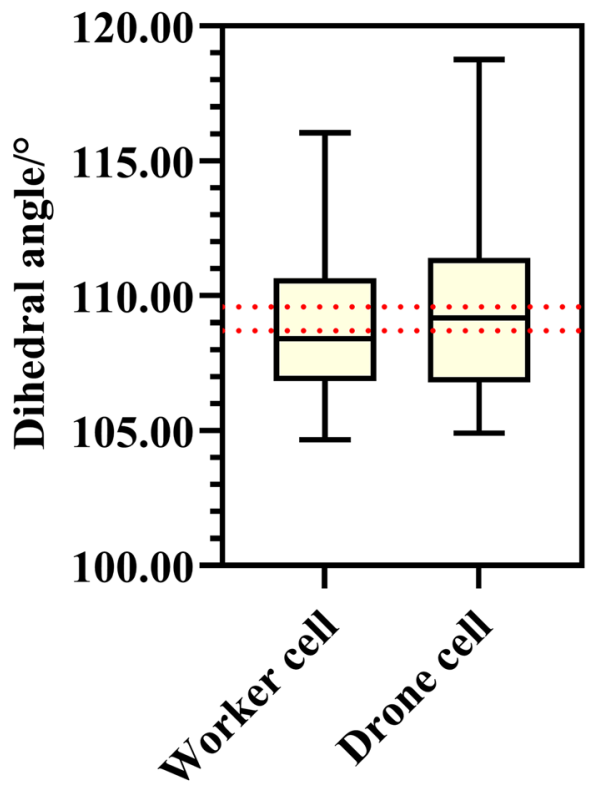

Cell type
KL (Figure 2). According to Tóth (1964), the theoretical dihedral angle of the two hexagonal planes (JKLGHI and BCDELK; Figure 2) of Fejes Tóth cells is $120^{\circ}$. The average dihedral angle between the hexagonal plane JKLGHI and the hexagonal plane BCDELK at the bottom of the WTC was $108.70^{\circ} \pm 0.20^{\circ}$ $\left(N_{\text {comb }}=24, N_{\text {cell }}=211\right)$, which is significantly lower than the theoretical value of $120^{\circ}$ $(t=56.56, \mathrm{df}=211, P<0.0001)$. The average dihedral angle between the hexagonal plane JKLGHI and the hexagonal plane BCDELK at the bottom of the DTC was $111.10^{\circ} \pm 0.26^{\circ}$ $\left(N_{\text {four drone combs }+ \text { ten mixed combs }}=14, N_{\text {cell }}=138\right)$, which is significantly lower than the theoretical value of $120^{\circ}(t=34.41, \mathrm{df}=137$, $P<0.0001)$. The dihedral angle data are shown in Figure $8 b$. (b)

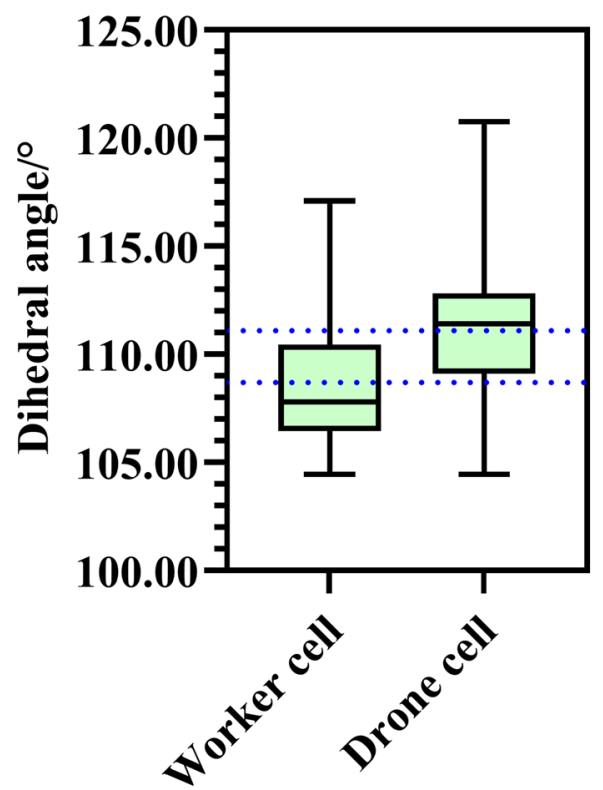

Cell type

Figure 8. Box plots of the dihedral angle of the two hexagonal planes at the bottom of Fejes Tóth cells. a Chinese bee; $\mathbf{b}$ Italian bee 


\subsection{Comparison of the diameter between Fejes Tóth cells and three-rhombus cells}

\subsubsection{Chinese bee combs}

There was no significant difference $(t=1.53$, $\mathrm{df}=423.7, P=0.1271)$ between the average diameter $\left(4.89 \mathrm{~mm} \pm 0.0081 \mathrm{~mm}, N_{\text {comb }}=23\right.$, $N_{\text {cell }}=242$ ) of WTC and the average diameter ( $\left.4.87 \mathrm{~mm} \pm 0.0055 \mathrm{~mm}, N_{\text {comb }}=23, N_{\text {cell }}=242\right)$ of worker three-rhombus cells. There was no significant difference $(t=0.30, \mathrm{df}=156, P=0.7620)$ between the average diameter of DTC $\left(5.56 \mathrm{~mm} \pm 0.0195 \mathrm{~mm}, N_{\text {comb }}=6, N_{\text {cell }}=79\right)$ and the average diameter $(5.55 \mathrm{~mm} \pm 0.0164 \mathrm{~mm}$, $\left.N_{\text {comb }}=6, N_{\text {cell }}=79\right)$ of drone three-rhombus cells.

\subsubsection{Italian bee combs}

There was no significant difference $(t=0.76$, $\mathrm{df}=422, P=0.4478)$ between the average diameter $\left(5.46 \mathrm{~mm} \pm 0.0075 \mathrm{~mm}, N_{\text {comb }}=24\right.$, $\left.N_{\text {cell }}=212\right)$ of WTC and the average diameter $\left(5.46 \mathrm{~mm} \pm 0.0071 \mathrm{~mm}, N_{\text {comb }}=24\right.$, $\left.N_{\text {cell }}=212\right)$ of worker three-rhombus cells. There was no significant difference $(t=1.26$, $\mathrm{df}=173.2, P=0.2079)$ between the average diameter of DTC $(6.73 \mathrm{~mm} \pm 0.0223 \mathrm{~mm}$, $N_{\text {four drone combs + six mixed combs }}=10, N_{\text {cell }}=118$ ) and the average diameter $(6.70 \mathrm{~mm} \pm 0.0113 \mathrm{~mm}$, $\left.N_{\text {four drone combs }+ \text { six mixed combs }}=10, N_{\text {cell }}=118\right)$ of drone three-rhombus cells.

\subsection{Comparison of the depth of Fejes Tóth cells and three-rhombus cells}

\subsubsection{Chinese bee combs}

There was no significant difference $(t=0.46$, $\mathrm{df}=482, P=0.6457)$ between the average depth $\left(12.22 \mathrm{~mm} \pm 0.1583 \mathrm{~mm}, N_{\text {comb }}=23\right.$, $\left.N_{\text {cell }}=242\right)$ of WTC and the average depth $\left(12.12 \mathrm{~mm} \pm 0.1396 \mathrm{~mm}, N_{\text {comb }}=23, N_{\text {cell }}=242\right)$ of worker three-rhombus cells. There was no significant difference $(t=0.35, \mathrm{df}=156$, $P=0.7303$ ) between the average depth of DTC $\left(11.62 \mathrm{~mm} \pm 0.1997 \mathrm{~mm}, N_{\text {comb }}=6, N_{\text {cell }}=79\right)$ and the average depth $(11.53 \mathrm{~mm} \pm 0.1674 \mathrm{~mm}$, $\left.N_{\text {comb }}=6, N_{\text {cell }}=79\right)$ of drone three-rhombus cells.

\subsubsection{Italian bee combs}

There was no significant difference ( $t=0.06, \mathrm{df}=422, P=0.9531)$ between the average depth $(12.47 \mathrm{~mm} \pm 0.1541 \mathrm{~mm}$, $\left.N_{\text {comb }}=24, N_{\text {cell }}=212\right)$ of WTC and the average depth $\left(12.46 \mathrm{~mm} \pm 0.1585 \mathrm{~mm}, N_{\text {comb }}=24\right.$, $\left.N_{\text {cell }}=212\right)$ of worker three-rhombus cells. There was no significant difference $(t=0.90$, $\mathrm{df}=234, P=0.3708)$ between the average depth of DTC $(13.67 \mathrm{~mm} \pm 0.1194 \mathrm{~mm}$, $N_{\text {four drone combs }+ \text { six mixed combs }}=10, N_{\text {cell }}=118$ ) and the average depth $(13.52 \mathrm{~mm} \pm 0.1114 \mathrm{~mm}$, $\left.N_{\text {four drone combs + six mixed combs }}=10, N_{\text {cell }}=118\right)$ of drone three-rhombus cells.

\subsection{Side lengths of the quadrilaterals and hexagons of the Fejes Tóth cell base}

The two quadrilaterals at the bottom of the Fejes Tóth cells were denoted as ABKJ and EFGL. The average lengths of the sides $\mathrm{AB}, \mathrm{BK}$, $\mathrm{KJ}$, and $\mathrm{JA}$ of the quadrilateral $\mathrm{ABKJ}$ and the average lengths of the sides EF, FG, GL, and EL of the quadrilateral EFGL are shown in Table I. The two hexagons were denoted as JKLGHI and BCDELK. The average lengths of the sides GH, $\mathrm{HI}, \mathrm{IJ}, \mathrm{KJ}, \mathrm{KL}$, and GL of the hexagon JKLGHI and the average lengths of the sides $\mathrm{BC}, \mathrm{CD}, \mathrm{DE}$, $\mathrm{EL}, \mathrm{KL}$, and $\mathrm{BK}$ of the hexagon BCDELK are shown in Table I. 
Table I

The average side length of the cell base (mean \pm S.E., unit: $\mathrm{mm})$

\begin{tabular}{|c|c|c|c|c|c|}
\hline \multirow[b]{3}{*}{ Polygon } & \multirow[b]{3}{*}{ Side } & \multicolumn{2}{|l|}{ A. c. cerana } & \multicolumn{2}{|l|}{ A. m. ligustica } \\
\hline & & \multicolumn{2}{|l|}{ Cell type } & \multicolumn{2}{|l|}{ Cell type } \\
\hline & & $\begin{array}{l}\text { Worker cell } \\
N_{\text {comb }}=23, \\
N_{\text {cell }}=242\end{array}$ & $\begin{array}{l}\text { Drone cell } \\
N_{\text {comb }}=6, \\
N_{\text {cell }}=79\end{array}$ & $\begin{array}{l}\text { Worker cell } \\
N_{\text {comb }}=24, \\
N_{\text {cell }}=212\end{array}$ & $\begin{array}{l}\text { Drone cell } \\
N_{\text {comb }}=10, \\
N_{\text {cell }}=118\end{array}$ \\
\hline \multirow[t]{4}{*}{ ABKJ } & $\mathrm{AB}$ & $1.595 \pm 0.0135$ & $1.841 \pm 0.0275$ & $1.828 \pm 0.0165$ & $2.242 \pm 0.0318$ \\
\hline & $\mathrm{BK}$ & $1.602 \pm 0.0130$ & $1.914 \pm 0.0262$ & $1.800 \pm 0.0179$ & $2.226 \pm 0.0313$ \\
\hline & $\mathrm{KJ}$ & $1.563 \pm 0.0110$ & $1.889 \pm 0.0241$ & $1.825 \pm 0.0168$ & $2.219 \pm 0.0293$ \\
\hline & JA & $1.597 \pm 0.0134$ & $1.905 \pm 0.0245$ & $1.810 \pm 0.0163$ & $2.158 \pm 0.0287$ \\
\hline \multirow[t]{4}{*}{ EFGL } & $\mathrm{EF}$ & $1.549 \pm 0.0131$ & $1.828 \pm 0.0276$ & $1.800 \pm 0.0197$ & $2.176 \pm 0.0305$ \\
\hline & FG & $1.530 \pm 0.0128$ & $1.829 \pm 0.0246$ & $1.761 \pm 0.0168$ & $2.140 \pm 0.0299$ \\
\hline & GL & $1.607 \pm 0.0134$ & $1.904 \pm 0.0251$ & $1.880 \pm 0.0184$ & $2.254 \pm 0.0336$ \\
\hline & EL & $1.624 \pm 0.0127$ & $1.930 \pm 0.0226$ & $1.814 \pm 0.0179$ & $2.185 \pm 0.0296$ \\
\hline \multirow[t]{6}{*}{ JKLGHI } & $\mathrm{GH}$ & $1.666 \pm 0.0136$ & $1.929 \pm 0.0279$ & $1.846 \pm 0.0182$ & $2.194 \pm 0.0291$ \\
\hline & $\mathrm{HI}$ & $1.956 \pm 0.0145$ & $2.163 \pm 0.0283$ & $2.438 \pm 0.0248$ & $2.908 \pm 0.0347$ \\
\hline & IJ & $1.602 \pm 0.0130$ & $1.889 \pm 0.0288$ & $1.829 \pm 0.0194$ & $2.311 \pm 0.0360$ \\
\hline & $\mathrm{KJ}$ & $1.563 \pm 0.0110$ & $1.889 \pm 0.0241$ & $1.825 \pm 0.0168$ & $2.219 \pm 0.0293$ \\
\hline & KL & $1.905 \pm 0.0126$ & $2.294 \pm 0.0273$ & $2.363 \pm 0.0214$ & $2.876 \pm 0.0353$ \\
\hline & GL & $1.607 \pm 0.0134$ & $1.904 \pm 0.0251$ & $1.880 \pm 0.0184$ & $2.254 \pm 0.0336$ \\
\hline \multirow[t]{6}{*}{ BCDELK } & $\mathrm{BC}$ & $1.652 \pm 0.0150$ & $1.978 \pm 0.0288$ & $1.821 \pm 0.0182$ & $2.207 \pm 0.0340$ \\
\hline & $\mathrm{CD}$ & $1.964 \pm 0.0159$ & $2.164 \pm 0.0292$ & $2.473 \pm 0.0240$ & $2.934 \pm 0.0373$ \\
\hline & $\mathrm{DE}$ & $1.615 \pm 0.0147$ & $1.892 \pm 0.0282$ & $1.865 \pm 0.0191$ & $2.316 \pm 0.0340$ \\
\hline & EL & $1.624 \pm 0.0127$ & $1.930 \pm 0.0226$ & $1.814 \pm 0.0179$ & $2.185 \pm 0.0296$ \\
\hline & KL & $1.905 \pm 0.0126$ & $2.294 \pm 0.0273$ & $2.363 \pm 0.0214$ & $2.876 \pm 0.0353$ \\
\hline & $\mathrm{BK}$ & $1.602 \pm 0.0130$ & $1.914 \pm 0.0262$ & $1.800 \pm 0.0179$ & $2.226 \pm 0.0313$ \\
\hline
\end{tabular}

\section{DISCUSSION}

\subsection{Honey bee comb cells with Fejes Tóth structure}

Studies from the nineteenth century provide some information on the structure of honey bee comb cells. Four polygonal planes were noted at the bottom of the cells during comb cell construction, including two symmetrical hexagonal planes and two symmetrical rhombic planes (Huber 1814; Wyman 1866). Huber (1814) and Wyman (1866) drew pattern diagrams of these cells and described their structural characteristics in detail. Fejes Tóth (1964) proposed the Fejes Tóth structure and showed that the surface area of cells with this structure is smaller than the surface area of three-rhombus cells when the cells are equal in volume. Huber (1814) and Wyman (1866) found that the cells on honey bee natural combs have a Fejes Tóth structure. However, cells with Fejes Tóth structure, and their reduced construction costs compared with three-rhombus cells, were not formally recognized until 1964. Interest in Fejes Tóth cells has increased in recent years, and these studies have found that the natural combs of Chinese bees and Italian bees contain some 
Fejes Tóth cells, indicating that Fejes Tóth cells do actually exist in the natural combs of Chinese bees and Italian bees.

\subsection{Percentage of cells of different structures}

The average percentage of the number of Fejes Tóth cells to C was no more than $18 \%$ for natural combs. In other words, the average percentage of the number of three-rhombus cells to $\mathrm{C}$ was greater than $82 \%$, indicating that although bees can build Fejes Tóth cells, they prefer to build three-rhombus cells. This may be explained by the greater complexity and difficulty of constructing Fejes Tóth cells compared with threerhombus cells. However, Tóth (1964) and Vallo et al. (2014) showed that the surface area of three-rhombus cells is greater than that of Fejes Tóth cells when these two types of cells have the same volume. Given that the amount of beeswax consumed to construct three-rhombus cells is greater than that consumed to construct Fejes Tóth cells, there is a trade-off between Fejes Tóth cell construction and food consumption. The empirically identified Fejes Tóth cells differ from the theoretical Fejes Tóth cells, especially in the angles between the hexagonal planes. Nevertheless, this deviation from ideal Fejes Tóth cells may still reduce construction costs. Although the percentage of three-rhombus cells was $82 \%$ and that of Fejes Tóth cells was $18 \%$ in this study, the outcome of this trade-off might vary among bee species and environmental conditions (e.g., lack of nectar and low colony strength).

\subsection{Dihedral and plane angles of Fejes Tóth cells}

According to Tóth (1964), the theoretical dihedral angle of the two hexagonal planes (JKLGHI and BCDELK; Figure 2) of the Fejes Tóth structure is $120^{\circ}$. However, the average dihedral angle of the hexagonal planes JKLGHI and BCDELK at the bottom of the Fejes Tóth cells in our study was approximately $10-12^{\circ}$ smaller than the theoretical value $\left(120^{\circ}\right)$. There are two possible explanations for this difference. On the one hand, the structure of Fejes Tóth cells is more complex than the structure of three-rhombus cells, and the difficulty of constructing Fejes Tóth cells is greater than constructing three-rhombus cells. On the other hand, the ability of honey bees to perceive angles is limited compared with their ability to perceive linear lengths (Hepburn 1986; Hepburn and Whiffler 1991). Honey bees have been shown to perceive angles and lengths via sensory receptors on the neck and antennae (Gontarski 1949; Martin and Lindauer 1966). However, perception via these receptors is limited. Although the structure of three-rhombus cells is not complex, bees are still unable to construct rhombuses with obtuse and acute angles at theoretical optima $\left(109^{\circ} 28^{\prime}\right.$ and $70^{\circ}$ $32^{\prime}$, respectively) (Goss et al. 2020).

The prototype of the Fejes Tóth structure is a truncated octahedron with six corners cut off. The truncated octahedron comprises two symmetrical squares with parallel median lines. Along the plane of the median lines of the squares, the truncated octahedron is divided into two identical geometric polyhedrons, which are Fejes Tóth structures. If the regular hexagonal cell mouth is ignored, there are five types of dihedral angles between the four faces at the bottom of Fejes Tóth cells and between the four faces and the cell walls. The five types of dihedral angles include that between hexagonal plane JKLGHI and hexagonal plane BCDELK, hexagonal plane JKLGHI and rectangular cell wall, hexagonal plane JKLGHI and pentagonal cell wall, hexagonal plane JKLGHI and rhombic plane $\mathrm{ABKJ}$, and rhombic plane ABKJ and the wall of the pentagonal cell, which are denoted as $\boldsymbol{\varepsilon}, \boldsymbol{\eta}, \boldsymbol{\lambda}, \boldsymbol{\mu}$, and $\boldsymbol{\sigma}$, respectively. The side length parameters of each polygon of the truncated octahedron provided by Tóth (1964) can be calculated as $\cos \varepsilon=-\frac{1}{2}$, $\cos \boldsymbol{\eta}=-\frac{1}{2}, \cos \lambda=-\frac{1}{4}, \cos \boldsymbol{\mu}=-\frac{\sqrt{6}}{4}$, and $\cos$ 
$\boldsymbol{\sigma}=-\frac{\sqrt{6}}{4}$. Therefore, the theoretical values of the dihedral angles $\boldsymbol{\varepsilon}, \boldsymbol{\eta}, \boldsymbol{\lambda}, \boldsymbol{\mu}$, and $\boldsymbol{\sigma}$ are $120^{\circ}$, $120^{\circ}, 104.48^{\circ}, 127.76^{\circ}$, and $127.76^{\circ}$, respectively. The four faces at the bottom of the Fejes Tóth cell have four types of plane angles, which include the two angles of the hexagon JKLGHI (angle IJK and angle JKL) and two angles of the rhombus ABKJ (angle JAB and angle $\mathrm{ABK})$, which are denoted as $\boldsymbol{\alpha}, \boldsymbol{\beta}, \boldsymbol{\gamma}$, and $\boldsymbol{\theta}$ and can be calculated as $\cos \boldsymbol{\alpha}=-\frac{3}{5}, \cos \boldsymbol{\beta}=-\frac{\sqrt{5}}{5}$, $\cos \gamma=-\frac{1}{5}$, and $\cos \theta=\frac{1}{5}$, respectively. Therefore, the theoretical values of the plane angles $\boldsymbol{\alpha}, \boldsymbol{\beta}, \boldsymbol{\gamma}$, and $\boldsymbol{\theta}$ are $126.86^{\circ}, 116.57^{\circ}, 101.54^{\circ}$, and $78.46^{\circ}$, respectively. For the development of the Fejes Tóth comb foundation machine, the relative angle of the cell base mold of the comb foundation machine should be based on the angle parameters of the ideal structure of the Fejes Tóth cell (i.e., the aforementioned angle data).

\subsection{Diameter of honey bee Fejes Tóth cells}

Although the structure of the bottom of Fejes Tóth cells differs from that of threerhombus cells, the diameter of Fejes Tóth cells is the same as that of three-rhombus cells, which means that the diameter of cells is not altered by bees. Honey bees build the base of cells first; when the cell base is as large as the cell diameter, the cell walls begin to form (Nazzi 2016; Oeder and Schwabe 2017), which indicates that the diameter of cells is mainly determined by the size of the bottom of the cell. Fejes Tóth cells and three-rhombus cells have the same diameter, and the projections on the front of the bottom of the cells (Fejes Tóth cell, three-rhombus cell) are regular hexagons with the same dimensions. Therefore, the diameter of the Fejes Tóth cell base mold was the same as that of the three-rhombus cell base mold, but the structures differed. The diameter of the cell base mold of the comb foundation machine is based on the diameter of the natural comb of honey bee species.

\subsection{Depth of honey bee Fejes Tóth cells}

The depth of Fejes Tóth cells is mainly determined by the honey bees and varies with cell type. For example, the bee space of natural nests ranges from 6.4 to $19.0 \mathrm{~mm}$, and the bee space in the honey storage area is narrower than that between the combs (Taber and Owens 1970), which indicates that the depth of the cells in the honey storage area is greater than that in the brood area. The average depth of worker cells $(11.00 \mathrm{~mm})$ is smaller than that of drone cells $(12.50 \mathrm{~mm}$ ) (Seeley and Morse 1976). Thus, cell depth is not related to cell structure but depends more on the needs of honey bees. Manufacturers of plastic combs should ensure that the depth of Fejes Tóth cells is set based on the needs of honey bees when producing plastic combs with Fejes Tóth cells.

\subsection{Side lengths of the polygon at the bottom of Fejes Tóth cells}

We calculated the length of each side of hexagon JKLGHI and rhombus ABKJ at the bottom of Fejes Tóth cells according to the side length parameters of each polygon of the truncated octahedron provided by Tóth (1964). The diameter of the cell is denoted by $\mathbf{d}$, and the width of the cell wall (the side length of the regular hexagonal cell mouth) is denoted by $\mathbf{s}$. We can then determine that $\mathbf{d}=\sqrt{3} \boldsymbol{s}$ for hexagon JKLGHI, where $\mathrm{HI}=\mathrm{KL}=\mathbf{s}=\frac{\boldsymbol{d}}{\sqrt{3}}, \mathrm{IJ}=\mathrm{KJ}=\mathrm{GL}=\mathrm{GH}=$ $\frac{\sqrt{5}}{4} \boldsymbol{s}=\frac{\sqrt{15}}{12} \boldsymbol{d}$; for rhombus $\mathrm{ABKJ}, \mathrm{AB}=\mathrm{BK}=$ $\mathrm{KJ}=\mathrm{JA}=\frac{\sqrt{5}}{4} s=\frac{\sqrt{15}}{12} d$. If the diameter of the cell or the side length of the cell mouth is measured, the length of each side of the polygon at the bottom of the Fejes Tóth cell can be calculated by the above formula, and this information can aid the manufacture of Fejes Tóth comb foundation machines. To obtain the ideal structure of Fejes Tóth cells, the side length of the polygon cell base mold of the comb foundation machine should be based on these theoretical lengths rather than on the actual side lengths of the polygon at the bottom of Fejes Tóth cells. Several 
outstanding questions require consideration: Once the Fejes Tóth wax comb foundation is obtained, is the strength of the Fejes Tóth wax comb foundation higher than the standard wax comb foundation? Which wax comb foundation permits bee colonies to build combs more rapidly? and How much beeswax can be saved via Fejes Tóth combs? We plan to address these questions in our future research.

\section{CONCLUSIONS}

In this study, we showed that the natural combs of Chinese bees and Italian bees are mainly composed of three-rhombus cells and a small proportion of Fejes Tóth cells. There are two types of Fejes Tóth cells: WTC and DTC. Measurements of the side lengths of four polygons and the dihedral angle of two planes at the bottom of Fejes Tóth cells revealed differences between Fejes Tóth cells constructed by honey bees and the theoretically optimal Fejes Tóth structure. The diameter and depth of Fejes Tóth cells were not significantly different from the diameter and depth of three-rhombus cells. The diameter of natural honey bee comb cells should be used as the diameter of the cell base mold of the comb foundation machine for the production of plastic combs with Fejes Tóth structure. The formulas provided in this paper can be used to determine the side lengths of each polygon of the cell base mold of the comb foundation machine, the diameter of Fejes Tóth cells, and other manufacturing parameters (the interior angle of the polygons and the dihedral angles between the polygons).

\section{ACKNOWLEDGEMENTS}

We thank Mrs. Zhou and Mrs. Liu for their help with bee colony management. We thank Shaojie Shi, Hailong Zuo, Cheng Zhou, and Yue Zhou for their help with preliminary treatments, measurements, and test samples. We thank TopEdit (www.topeditsci.com) for editing the English text of a draft of this manuscript.

\section{AUTHOR CONTRIBUTION}

Conceptualization, K.D. and S.Y.; methodology, S.Y. and X.G.; performed the experiments, S.Y., X.G., D.Z., X.Z., and H.K.; analyzed the data and prepared the figures, S.Y. and K.D.; writing - original draft preparation, S.Y.; writing - review and editing, K.D., S.Y., and X.G. All authors have read and agreed to the published version of the manuscript.

\section{FUNDING}

This study was supported by grants from the National Natural Science Foundation of China (Nos. 32060241 and 31572339), the China Agriculture Research System of the Ministry of Finance and the Ministry of Agriculture and Rural Affairs (CARS-44-KXJ13), and the Reserve Talents Training Program for Young and Middle-aged Academic and Technical Leaders in Yunnan (No. 2018HB041).

\section{AVAILABILITY OF DATA AND MATERIAL}

The preprocessed data that support the findings of this study are available from the corresponding author upon reasonable request.

\section{CODE AVAILABILITY}

Not applicable.

\section{DECLARATIONS}

Ethics approval Not applicable.

Consent to participate Not applicable.

Consent for publication Not applicable.

Conflict of interest The authors declare no competing interests.

Open Access This article is licensed under a Creative Commons Attribution 4.0 International License, which permits use, sharing, adaptation, distribution and reproduction in any medium or format, as long as you give appropriate credit to the original author(s) and the source, provide a link to the Creative Commons licence, and indicate if changes were made. The images or other third party material in this article are included in the article's Creative Commons licence, unless indicated otherwise in a credit line to the material. If material is not included in the article's Creative Commons licence and your intended 
use is not permitted by statutory regulation or exceeds the permitted use, you will need to obtain permission directly from the copyright holder. To view a copy of this licence, visit http://creativecommons.org/licenses/by/4.0/.

\section{REFERENCES}

Bauer D., K. Bienefeld. (2013) Hexagonal comb cells of honeybees are not produced via a liquid equilibrium process. Naturwissenschaften 100(1): 45-49.

Everett J.D. (1903) XXVI. On the mathematics of Bees' cells. The London, Edinburgh, and Dublin Philosophical Magazine and Journal of Science 6(32): 228-230.

Frisch K.v., O.v. Frisch. (1974) Animal architecture. Harcourt Brace Jovanovich, New York.

Glaisher B.A. J.W.L. (1873) XI. On the form of the cells of bees. The London, Edinburgh, and Dublin Philosophical Magazine and Journal of Science 46(304): 103-122.

Gontarski H. (1949) Über die Vertikalorientierung der Bienen beim Bau der Waben und bei der Anlage des Brutnestes. Zeitschrift fr Vergleichende Physiologie 31(5): 652-670.

Goss D., Y. Mistry, S. Niverty, C. Noe, B. Santhanam, et al. (2020) Bioinspired Honeycomb Core Design: An Experimental Study of the Role of Corner Radius, Coping and Interface. Biomimetics 5(4): 59.

Graesser R.F. (1946) Some mathematics of the honey comb. School Science and Mathematics 46(4): 339-343.

Hennessy H. (1885) IV. On the geometrical construction of the cell of the honey bee. Proceedings of the Royal Society of London 39(239-241): 253-254.

Hepburn H., L. Whiffler. (1991) Construction defects define pattern and method in comb building by honeybees. Apidologie 22(4): 381-388.

Hepburn H.R. (1986) Honeybees and Wax An Experimental Natural History. Springer, Berlin, Heidelberg.

Hepburn H.R., C.W.W. Pirk, O. Duangphakdee. (2014) Honeybee Nests. Springer, Berlin Heidelberg.

Huber F. (1814) Nouvelles Observations sur les Abeilles. J. J. Paschoud, Paris.

Jeong D., Y. Choi, J. Kim. (2018) Modeling and simulation of the hexagonal pattern formation of honeycombs by the immersed boundary method. Communications in Nonlinear Science and Numerical Simulation 62: 61-77.

Jeong D., Y. Li, S. Kim, Y. Choi, C. Lee, et al. (2019) Mathematical modeling and computer simulation of the three-dimensional pattern formation of honeycombs. Scientific Reports 9(1): 20364.

Johansson T.S.K., M.P. Johansson. (1969) The Development of Comb Foundation. Bee World 50(2): 61-65.

Karihaloo B.L., K. Zhang, J. Wang. (2013) Honeybee combs: how the circular cells transform into rounded hexagons. Journal of the Royal Society Interface 10(86): 1-4.

Kepler J. (1619) Harmonices Mundi. Johann Planck for Gottfried Tampach, Linz.
Khamdaeng T., T. Wongsiriamnuay, N. Panyoyai, K. Narkprasom, W. Intagun. (2016) Mechanical properties and melting conditions of beeswax for comb foundation forming. Agricultural Engineering International 18(3): 282-293.

Mackenzie D. (1999) MATHEMATICS:Proving the Perfection of the Honeycomb. Science 285(5432): 1338-1339.

MacLaurin C. (1743) I. Of the bases of the cells wherein the bees deposite their honey. Part of a letter from Mr. MacLaurin, Professor of Mathematics at Edinburgh, and F. R. S. to Martin Folkes, Esq; Pr. R. S. Philosophical Transactions of the Royal Society of London 42(471): 565-571.

Manby R.O.B. (1932) Comb Foundation-Plain and ReInforced. Bee World 13(9): 100-102.

Martin H., M. Lindauer. (1966) Sinnesphysiologische Leistungen beim Wabenbau der Honigbiene. Zeitschrift für vergleichende Physiologie 53(3): 372-404.

Narumi T., K. Uemichi, H. Honda, K. Osaki. (2018) Selforganization at the first stage of honeycomb construction: Analysis of an attachment-excavation model. PLoS One 13(10): e0205353.

Nazzi F. (2016) The hexagonal shape of the honeycomb cells depends on the construction behavior of bees. Scientific Reports 6(28341): 1-6.

Oeder R., D. Schwabe. (2017) Evidence that no liquid equilibrium process is involved in the comb building of honey bees (Apis Mellifera). Oberhessische Naturwissenschaftliche Zeitschrift 67: 8-26.

Oeder R., D. Schwabe. (2021) The upward tilt of honeycomb cells increases the carrying capacity of the comb and is not to prevent the outflow of honey. Apidologie 52(3): 174-185.

Oelsen G., E. Rademacher. (1979) Untersuchungen Zum Bauverhalten Der Honigbiene (Apis Mellifica). Apidologie 10(2): 175-209.

Oldroyd B.P., S.C. Pratt. (2015) Chapter Four Comb Architecture of the Eusocial Bees Arises from Simple Rules Used During Cell Building. Advances in Insect Physiology 49: 101-121.

Pellett F.c. (2010) The Development of Wax Foundation. American Bee Journal 150(4): 341-343.

Peterson I. (1999) The honeycomb conjecture: Proving mathematically that honeybee constructors are on the right track. Science News 156(4): 60-61.

Pirk C.W., H.R. Hepburn, S.E. Radloff, J. Tautz. (2004) Honeybee combs: construction through a liquid equilibrium process? Naturwissenschaften 91(7): 350-353.

Räz T. (2017) The silent hexagon: explaining comb structures. Synthese 194(5): 1703-1724.

Saucy F. (2014) On the natural cell size of European honey bees: a "fatal error" or distortion of historical data? Journal of Apicultural Research 53(3): 327-336.

Seeley T.D. (1985) Honeybee ecology : a study of adaptation in social life. Published by Princeton University Press, Princeton, New Jersey. 
Seeley T.D., R.A. Morse. (1976) The nest of the honey bee (Apis mellifera L.). Insectes Sociaux 23(4): 495-512.

Sharpe S. (1828) Vi. On the figure of the cells of the honeycomb. The Philosophical Magazine 4(19): 19-21.

Smith F.G. (1960) Comb Foundation: Its use for African Honeybees. Bee World 41(9): 235-240.

Svečnjak L., L.A. Chesson, A. Gallina, M. Maia, M. Martinello, et al. (2019) Standard methods for Apis mellifera beeswax research. Journal of Apicultural Research 58(2): 1-108.

Taber S., C.D. Owens. (1970) Colony founding and initial nest design of honey bees, Apis mellifera L. Animal Behaviour 18(4): 625-632.

Talukdar D., K. Dutta. (2019) A simplified thermomechanical approach to visualize hexagonal honeycomb construction. SN Applied Sciences 1(10): 1220.

Tautz J. (2008) The Buzz about Bees: Biology of a Superorganism. Springer, Berlin.
Tóth L.F. (1964) What the bees know and what they do not know. Bulletin of the American Mathematical Society 70(4): 468-482.

Vallo D., V. Duris, L. Rumanova. (2014) Geometry of bee cells rediscovered. The Electronic Journal of Mathematics and Technology 8(3): 178-194.

Weaire D., R. Phelan. (1994) Optimal design of honeycombs. Nature 367(6459): 123-123.

Wyman J. (1866) Notes on the Cells of the Bee. Proceedings of the American Academy of Arts and Sciences 7(1): 1-18.

Publisher's Note Springer Nature remains neutral with regard to jurisdictional claims in published maps and institutional affiliations. 